\title{
PENGEMBANGAN KEPEMIMPINAN SEORANG PELAYAN DAN PELAYANAN SEORANG PEMIMPIN
}

\section{Hadi P Sahardjo}

\section{ABSTRAK}

Sebuah lembagan atau organisasi apa pun dan mana pun, pasti ada yang dinamakan pemimpin. Pemimpin dibutuhkan untuk membawa organisasi yang dipimpinnya bergerak maju dalam arahan dan tujuan yang telah ditetapkan. Pemimpin harus bisa mengatur tapi bukanlah pengatur segalanya. Dia tidak bisa menjadi pemimpin tanpa ada yang dipimpin. Dia sebagai penggerak yang tidak bisa bergerak sendiri; sementara yang menggerakkan adalah Tuhan, dan dia menggerakkan orang-orang yang dipimpinnya dengan kasih dan bijaksana. Karena memimpin bukan sekedar talenta dan skill, tetapi adalah juga seni. Tidak hanya membutuhkan kemampuan, tetapi juga bagaimana menghargai dan membangun relasi dengan orang-orang yang dipimpinnya. Karena sesungguhnya pemimpin bukanlah "tuan" melainkan "hamba".

Kata kunci: pemimpin, menggerakkan, talenta, skill, tuan, hamba, mandat.

\section{PENDAHULUAN}

Menjadi pemimpin bukanlah suatu kebetulan, tapi sebuah mandat dan kepercayaan. Seseorang bisa saja menjadi pempimpin tapi tidak bisa memimpin. Dalam teori kepemimpinan kita mengenal ada beberapa pempimpin, yaitu pemimpin yang mendapatkan kepemimpinannya dengan cara: by delegation, by custom atau by tradition, by authority, by personality, by accident, dsb. Kepemimpinan by delegation adalah kepemimpinan yang diperoleh karena ditunjuk atau didelegasikan. Mungkin orang itu tidak memiliki kapasitas sebagai pemimpin, tapi karena ditunjuk, ya jadilah dia sebagai pemimpin. Lalu kepemimpinan by custom atau by tradition. Ini adalah kepemimpinan yang diterima secara turun-temurun atau diwariskan, seperti pada sistem monarki atau kerajaan. Di sini ada putra mahkota yang dipersiapkan untuk menggantikann Sang Raja atau pemimpin. Karena asudah dipersiapkan, maka tentu mereka juga dibekali dengan pelbagai 
macam teori kepemimpinan yang baik. Selanjutnya ada kepemimpinan yang diperoleh by authority. Di sini seseorang bisa menjadi pemimpin oleh karena memiliki otoritas atau kemampuan yang mumpuni. Ini seringkali bisa muncul dengan sendirinya, tapi ada yang mengangkatnya menjadi pemimpin karena dia memang layak dan memiliki kemapuan atau kapasitas untuk itu. Kemudian ada lagi kepemimpinan yang diperoleh by personality. Mungkin dari segi kepemimpinan tidak terlalu bagus, biasa-biasa saja, tetapi dia disukai sebagai pemimpin karena kepribadiannya yang bisa menjadi penutan. Lalu ada kepemimpinan lagi yang diperoleh by accident. Ini benar-benar ibarat mendapat durian runtuh atau rejeki nomplok. Bagaimana tidak? Ia dipilih untuk menjadi pemimpin karena karena memang sedang dibutuhkan atau tidak ada orang lain yang bisa menjadi pemimpin. Mungkin orang itu adalah yang terbaik dari antara yang terjelek. Namun demikian tidak mustahil pula orang akan terbentuk menjadi seorang pemimpin seiring dengan berjalannya waktu. Tetapi dalam dunia kekristenan menurut penulis, seorang pemimpin seharusnya adalah seorang benar-benar memeroleh visi dan misi serta panggilan yang jelas dari Tuhan, dan bukan sekedar ambisi.

Tulisan ini tidak hendah memaparkan terori-teori kepemimpinan yang sama sekali baru, namun mencoba untuk menyajikannya dari sisi yang berbeda sebagai penyegaran (refresh) saja. Di samping itu ada beberapa hal yang bagi penulis sangat perlu untuk kembali disimak oleh para pemimpin Kristen, agar bisa membuat refleksi diri, sehingga tidak selalu merasa diri sebagai pemimpin, karena sesungguhnya kita ini adalah "hamba." Sebaliknya juga jangan oleh karena label sebagai "hamba" yang melekat itu lalu menjadikannya minder, sehingga menghambat tugas dan pelayanan yang dipercayakan oleh Tuhan. Karena bagaimana pun, seorang pemimpin Kristen adalah seorang utusan dan wakil Tuhan.

\section{KEPEMimpinan SEORANG PELAYAN}

Seperti apakah kepemimpinan seorang pelayan itu? Robert Cueni' ${ }^{1}$, dalam bukunya yang berjudul: The Vital Church Leader, mengemukakan

${ }^{1}$ Robert Cueni. The Vital Church Leader: In Effective Chuch Series. (Abingdon Press, Nashville: 1991), 19-124. 
tentang ciri-ciri kepemimpinan seorang gembala secara garis besar dirumuskan dalam sepuluh pokok sebagai berikut:

1. Seorang pemimpin harus tabu bagaimana harus memimpin orang lain. Seorang pemimpin harus mampu memimpin orang lain, membangun kepercayaan terhadap orang lain dan orang lain terhadap dirinya. Seorang pemimpin harus memimpin di depan, bukan mengikuti dari belakang. Domba-domba itu membutuhkan gembala, yang memimpin mereka. Seorang pemimpin adalah seorang yang bisa knows the way, goes the way dan shows the way (mengetahui, membawa atau pergi dan menunjukkan jalan) pada para pengikutnya. ${ }^{2}$ Pemimpin juga harus mampu mengubah dan menjadikan para pengikutnya atau orang lain itu sebagai pelaku-pelaku aktif untuk memerkokoh kepemimpinan dan tujuan bersama yang dibangun. Seorang pemimpin tidak mencari keuntungan bagi dirinya sendiri, tetapi selalu siap untuk menerima pembaruan.

2. Seorang pemimpin harus mampu membawa orang lain kepada visi yang tertentu dan jelas. Pemimpin harus tahu bahwa apa yang dilakukan itu berdasarkan pada panggilan Kristus dan iman yang dimilikinya. Dia harus mampu memadukan dan membangun visi yang sama dengan jemaat untuk suatu tujuan yang mulia. Karena itu pemimpin harus jeli dengan visi jemaat, dan yang baik perlu didukung.

3. Seorang pemimpin harus mampu memotivasi orang lain. Ia harus menyadari bahwa tanpa peran orang lain pemimpin tidak akan bisa mencapai tujuan yang baik dan berhasil. Karena itu penting sekali seorang pemimpin mendorong orang lain agar juga memiliki kemampuan untuk bisa melakukan yang seharusnya. Jika pemimpin tidak mau melakukan itu, berarti ia telah gagal.

4. Seorang pemimpin harus bisa memberikan semangat dan membakar keberanian orang lain. Pemimpin harus mampu membakar orang lain untuk berani mengambil keputusan, langkah atau tindakan yang positif meskipun hal itu sering mengandung suatu risiko.

5. Seorang pemimpin harus mampu memberikan keteladanan yang baik. Dengan menjadikan dirinya sebagai model, maka mau tidak mau pemimpin

${ }^{2}$ Curtis Thomas, Practical Wisdom ..., 94. 
menuntut diri untuk terus berkembang. Ini juga penting dalam rangka memerkokoh kinerja kelompok. Berikanlah contoh yang positif. Seorang pemimpin yang kesaksiannya jelek, tidak bisa menjadi teladan. Bila perlu dengan mengorbankan dirinya, sebagaimana telah dilakukan oleh Tuhan Yesus.

6. Seorang pemimpin harus memiliki harapan yang terbaik. Apa yang ada di pikirannya harus yang terbaik, bukan sekedar yang baik. Dengan demikian akan ada satu target optimal yang bisa dicapai. Motto yang harus dipakai: "Why Not the Best?" Seperti iklan sebuah produk "Kalau bisa nomor 1, buat apa nomor 2 dan 3?"

7. Seorang pemimpin harus menjadi seorang pekerja keras. Seorang pekerja keras, tidak mengenal lelah dan gampang menyerah. Prinsip Paulus adalah bekerja keras, dan tidak mau membebani orang lain. “... Sebaliknya, aku telah bekerja lebih keras dari pada mereka semua; tetapi bukannya aku, melainkan kasih karunia Allah yang menyertai aku. ... Aku banyak berjerih lelah dan bekerja berat; kerap kali aku tidak tidur; aku lapar dan dahaga; kerap kali aku berpuasa, kedinginan dan tanpa pakaian," (1Kor. 15:10; 2 Kor. 11:27).

8. Seorang pemimpin juga harus mampu memanej tugas dan pelayanannya. (1) menjaga atau menempatkan prioritas, (2) mengenal batas, waktu dan kemampuannya, (3) mengenal jemaat dengan baik, (4) mencatat dan menyimpan dengan baik semua pelayanan, misalnya, khotbah, dan lain-lain (5) berani menolak terhadap sesuatu yang hanya menyenangkan orang lain.

9. Seorang pemimpin harus harus berani mengambil risiko dan tanggung jawab. Janganlah melepaskan tanggung jawab atau menyalahkan orang lain apabila terjadi suatu kegagalan atau kesalahan. Lihat dan koreksi diri sendiri terlebih dulu. Berani mengambil risiko bukan berarti bersikap sembarangan, tetapi segala sesuatu yang telah menjadi tekad, risiko apa pun yang akan terjadi harus dihadapi dengan sikap terbuka.

10. Seorang pemimpin harus mengasibi orang lain/pengikutnya. Ini suatu tuntutan yang mutlak. Allah mendemonstrasikan kasih-Nya melalui Yesus Kristus yang diberikan untuk kita. Tuhan Yesus juga memberikan perintah dan teladan kasih yang sempurna (bdk. Yoh. 3:16; 15:11 dengan 1Kor. 13:1-8). Kasih menjadi fondasi yang amat kokoh dalam kepemimpinan. 
Salah satu kunci penentu keberhasilan pemimpin adalah, apakah dia memiliki kasih atau tidak.

11. Seorang pemimpin harus memiliki pandangan dan prinsip tentang pentingnya administrasi. Don Conant mengatakan: All managers need not be leaders, but all leaders must know how to manage. Seorang manajer memang tidak harus selalu menjadi pemimpin, tetapi seorang pemimpin harus tahu bagaimana memenej/mengatur. Karena itu bagi pemimpin yang baik, ia harus belajar memiliki keseimbangan antara kemampuan memimpin dengan kemampuan administrasinya. Karena seorang pemimpin adalah seorang organisator, supervisor, sekaligus administrator. Salah satunya adalah memanej manusia.

Untuk itu menurut Petrus Octavianus ${ }^{3}$, seorang pemimpin terlebih dahulu harus memiliki persiapan-persiapan dalam berbagai aspek, agar dia bisa menjadi seorang pemimpin yang baik, handal, bertanggung jawab dan yang terutama, takut akan Tuhan. Persiapan-persiapan yang harus dimiliki adalah:

- Persiapan rohani. Pada dasarnya seorang pemimpin rohani itu dipilih oleh Tuhan sendiri. Dalam hal ini Tuhan tidak melihat pada pendidikan, pengetahuan, dan sebagainya, tapi lebih pada bagaimana kerohanian seseorang yang berkenan di hati Tuhan. Perhtikan bagaimana Tuhan memilih Yosua dan Daud untuk menjadi pemimpin bangsa-Nya (1Sam. 13:14; Bil. 27:18-20).

- Persiapan materi. Dimaksudkan di sini adalah bagaimana seorang pemimpin itu harus rela berkorban demi melayani-Nya. Termasuk keluarga dan harta benda sekalipun, jika itu memang dikehendaki Tuhan. Bukan sebaliknya justru menuntut untuk mendapatkannya.

- Persiapan mental. Termasuk di dalamnya adalah kesediaan untuk mengerjakan pekerjaan-pekerjaan yang bagi orang lain dianggap hina; kesediaan dan komitmen untuk mengerjakan setiap pekerjaan dengan sempurna, “... seperti untuk Tuhan, dan bukan untuk manusia” (Kol. 3:23); kemudian kesediaan untuk merawat dan mengembangkan

${ }_{3}^{3}$ Petrus Octavianus, Manajemen dan Kepemimpinan Menurut Wabyu Allah (Departemen Literatur YPPII, Batu: 2007 [cet. Ke-6], 67-74 
kebiasaan yang baik; memerhatikan orang lain dan selalu waspada, yakni bisa hidup bersama dengan orang lain dalam suasana yang hangat.

- Hidup terbuka. Yakni terbuka terhadap pandangan orang lain, termasuk kritik serta mau mengakui kekurangan serta kesalahannya di hadapan orang lain.

\section{TindAKAN-TindAKAN KEPEMIMPINAN SEORANG PELAYAN}

Seorang penulis lain, Robert D. Dale 4 , dalam bukunya: Pastoral Leadership juga memberikan catatan penting bagi seorang gembala dengan menekankan pada tugas dan tindakan apa yang seharusnya dilakukan oleh seorang pemimpin jemaat atau gembala. Secara garis besar dapat dirangkumkan sbb.:

1. Sebagai seorang visioner. Berarti tidak mandeg dan puas dengan apa yang sudah dilakukan dan sedang dihadapi. Harus memiliki keinginan/kerinduan untuk terus berkembang dan maju dalam pelayanannya. Dr. Marthin Luther King dalam pidatonya yang sangat terkenal: "I have a dream" mengungkapkan cita-cita dan kerinduannya bahwa suatu saat nanti di Amerika akan ada persamaan hak dan kedudukan antara orang-orang kulit putih dengan kulit hitam. Tidak ada lagi penindasan dan diskriminasi. Motto ini hendaknya juga menjadi satu kerinduan/cita-cita yang bakal dilaksanakan demi kemajuan gereja dan jemaatnya.

2. Seorang yang melaksanakan impian dan harapan menjadi kenyataan. Keberhasilan seseorang seringkali dilandasi oleh adanya impian yang dicanangkan. Franklin Roosevelt berhasil membawa Amerika ke arah kemajuan yang dilandasi oleh mimpi (idealisme) nya yang tinggi.

3. Seorang yang bisa mengembangkan rasa ikut memiliki dan tanggung jawab (psychological ownship) bersama terhadap jemaatnya. Pemimpin yang baik akan rela membagi "kue" kekuasaan dan peran/tanggung jawabnya kepada jemaatnya.

${ }^{4}$ Robert D. Dale. Pastoral Leadership ..., 14-17 
4. Seorang yang berani mengambil risiko dari inisiatif dan tindakannya. Tindakan ini tentunya berdasar pada iman, yang berarti rela dan siap untuk menanggung segala risiko. Iman ini bukanlah tindakan yang membabi buta. Tetapi iman yang berdasar. Karena itu tindakan seorang gembala harus didasari oleh iman seperti itu, sebagaimana ditulis dalam Ibrani 11:1 "Iman adalah dasar dari segala sesuatu yang kita harapkan dan bukti dari segala sesuatu yang tidak kita lihat."

5. Seorang yang tidak biasa menunggu "biar sempurna dulu" sebelum bertindak. Kalau kesempatan harus bertindak itu sekarang, ya sekarang. Jangan menunggu kalau segala sesuatu sudah terasa siap. Risikonya bisa telambat atau bahkan tidak jadi sama sekali.

6. Seorang yang berani mengubah pengikutnya menjadi seorang pemimpin. Tujuan akhir pemimpin adalah Kerajaan Surga, yang memberikan "kemuliaan" dan penghargaan adalah Bapa di Surga. Konsekuensinya kita harus rela membagi "kemuliaan" itu dengan orang lain, yaitu jemaat kita. Banyak pemimpin yang tidak rela kalau bawahannya menjadi sama seperti dia atau bahkan melebihinya. Akibatnya dia mulai memasang berbagai strategi untuk menjegal atau menghalang-halangi kariernya. Seorang pemimpin harus berani memberikan kesempatan kepada mereka untuk bisa mengembangkan potensi kepemimpinan mereka sehingga perlu diberikan peran yang sepadan. Jangan merasa takut akan disaingi.

7. Seorang yang mampu menjaga keseimbangan antara teori dan praktik, antara tujuan dan hasil5 Membuat teori yang muluk-muluk itu gampang. Membuat banyak program hebat itu gampang. Yang sukar adalah menerapkan dan melakukannya. Karena itu seorang pemimpin jemaat harus mampu menjaga keseimbangan antara keduanya. Juga harus ada keseimbangan antara pelayanan administrasi/ organisasi dengan pelayanan rohani.

8. Seorang yang tahu kapan dan bagaimana harus mengikuti dan diikuti. Antara pemimpin dengan yang dipimpin, antara gembala dengan jemaat itu memiliki hubungan yang dinamis, tidak statis. Hubungan yang hidup.

${ }^{5}$ Bandingkan dengan Stephen Tong. Keseimbangan dalam Pelayanan. Surabaya: Yakin. 1976. 
Karena itu adakalanya dalam hal-hal tertentu seorang pemimpin berubah posisi menjadi yang dipimpin. Ini jangan dianggap sebagai sesuatu yang tidak wajar (misalnya dalam kepanitiaan, dan sebagainya). Seorang pemimpin tidak harus selalu memposisikan dirinya sebagai satu-satunya yang harus memimpin.

9. Seorang yang bisa menjadikan unsur-unsur jemaat memerankan tugas-tugas gembala. Anggota jemaat yang memang memiliki kemampuan dan "talenta" untuk bidang tertentu perlu diberi peranan dan dilibatkan dalam pelayanan. Semakin banyak yang dilibatkan akan semakin baik.

\section{PRINSIP-PRINSIP KEPEMIMPINAN}

Dalam bukunya, Lead On: Leadership that Endures in a Changing World, ${ }^{6}$ John Edmund Haggai secara detil membahas tentang duabelas prinsip kepemimpinan yang secara garis besar masing-masing dapat diringkas sebagai berikut: ${ }^{7}$

\section{Prinsip Visi}

Kepemimpinan yang baik harus dimulai dengan adanya visi yang jelas terlebih dahulu. Dengan adanya visi maka akan dapat ditentukan apa yang nantinya akan dilakukan oleh kelompok. Oleh karena itu seorang pemimpin/gembala harus mengetahui: (1) Apakah yang menjadi visinya (2) Harus tahu seberapa pentingnya visi itu. Ini adalah fondasi bagi pemimpin dan kepemimpinan yang benar. (3) Seorang pemimpin juga harus tahu dari mana datangnya visi itu, yakni dari Allah.

\section{Prinsip Perumusan Tujuan}

Untuk bisa mencapai tujuan yang sudah ditetapkan sesuai dengan visi gereja, dianjurkan agar gembala menerapkan prinsip perumusan tujuan yang jelas. Salah satunya yang sudah sangat populer yang kita kenal dengan istilah SMART, yang merupakan singkatan dari: Specific (khusus);

${ }^{6}$ John Edmund Haggai. Lead On: Leadership that Endures In a Changing World. (Singapore: Kobrey Press, 1986), 11-193

${ }^{7}$ Hadi P. Sahardjo. Pastoral Teologi (STTIAA, Pacet-Mojokerto: 1998), 87 dyb. 
Meassurable (dapat diukur); $\boldsymbol{A}$ ttainable (dapat dicapai); $\boldsymbol{R}$ ealistic (realistis, masuk akal) dan $\boldsymbol{T}$ angible (nyata). Dari sini nyata sekali bahwa suatu tujuan itu harus jelas kapan dimulai, dengan cara apa, di mana, bagaimana mencapai dan sebagainya.

\section{Prinsip Kasih}

Seorang pemimpin harus mendasarkan kepemimpinannya pada kasih, yaitu kasih kepada Allah, sesama (bawahan) bahkan juga dirinya sendiri. Ungkapan kasih yang baik terdapat dalam Galatia 5: 22-23 itu b isa dilukiskan demikian: (1) Sukacita itu adalah musik kasih; (2) Damai sejahtera adalah persetujuan kasih; (3) Kesabaran adalah ketahanan kasih; (4) Kemurahan adalah pelayanan kasih; (5) Kebaikan adalah tingkah laku kasih; (6) Kesetiaan adalah ukuran kasih. Apabila pemimpin mendasarkan kepemimpinannya seperti ini, maka ia akan kokoh, tidak gampang jatuh.

\section{Prinsip Kerendahan Hati}

Bukan rendah diri. Seorang pemimpin yang rendah hati akan bebas dari rasa keangkuhan dan harga diri yang terlalu tinggi. Kasih dan kerendahan hati merupakan ciri dan prinsip kepemimpinan yang sejati. Untuk mengembangkan sifat kerendahan hati, harus selalu memusatkan perhatian pada tingkah laku yang rendah hati dan menempatkan Kristus dalam hidup dan hatinya.

\section{Pengendalian Diri}

Pengendalian diri merupakan bukti penguasaan kasih. Kurang pengendalian diri berarti akan menghancurkan kepemimpinan sendiri. Bahkan secara langsung atau tidak langsung akan menjerumuskan orang yang dipimpinnya untuk mengikuti jejaknya.

\section{Prinsip Komunikasi}

Pemimpin adalah seorang komunikator yang harus memiliki kemampuan untuk berkomunikasi. Ini merupakan modal yang sangat berharga. Harus bisa memilih tujuan komunikasi yang benar. Dia juga harus berani menghancurkan penghalang-penghalang yang menjadi kendala 
komunikasinya. Bicarakan apa yang dikenal dan merupakan pengalaman pendengar, jangan selalu membicarakan dirinya melulu. Pendengar harus dimotivasi untuk bisa bersikap aktif dan interes.

\section{Prinsip Penanaman Modal}

Pemimpin itu ibarat seorang yang menanamkan modalnya. Ada prinsip menabur dan menuai. Ada dua macam manusia, yaitu yang menanamkan modal dan yang menerima. Jika prinsip penanaman modal ini berlaku dengan baik, kedua belah pihak akan sama-sama diuntungkan. Pemimpin tidak hanya menuntut, tetapi juga tahu bagaimana berbuat untuk orang lain. Prinsip Kristus: "Berilah dan kamu akan diberi, suatu takaran yang baik, ...." (Luk.6: 38).

\section{Prinsip Kesempatan}

Pemimpin harus bisa melihat kesempatan kapan pun dan di mana pun. Jangan selalu melihat kesalahan sebagai suatu hambatan. Sebaliknya justru harus berani melihat kesalahan sebagai suatu pelajaran berharga: (1) Akuilah kesalahan itu apabila kita menyadari hal tersebut. (2) Terimalah pertangungjawaban atas kesalahan yang terjadi. (3) Evaluasilah kekeliruan atau kerusakan yang menjadi penyebab mengapa sampai terjadinya kesalahan; (4) Lakukanlah penyelidikan yang mendalam penyebab terjadinya kesalahan itu; (5) Segera hapuskan penyebab-penyebab kesalahan itu; (6) Selamatkanlah apa yang masih dapat diselamatkan; (7) Perbaikilah cara kerja Anda sehingga kesalahan tidak terulang lagi; (8) Laksanakan program baru dengan segera; (9) Pergunakanlah kesalahan besar sebagai rambu-rambu atau peringatan bagi Anda, dan (10) Ingatlah, bahwa halangan-halangan itu justru seringkali juga bisa meningkatkan kepemimpinan kita.

\section{Prinsip Energi/Kekuatan}

Pemimpin yang menunjukkan semangat besar dan kekuatan akan bisa memeroleh keyakinan dari orang-orang lain. Ini bisa ditunjukkan melalui kerja keras, intelektualnya, emosinya (yang positif) serta komitmennya untuk bisa tetap bertahan menghadapi segala rintangan. 


\section{Prinsip Daya Tahan}

Keberhasilan seorang pemimpin akan bisa dilihat dari bagaimana ia dalam menghadapi tantangan, rintangan, tekanan-tekanan, atau masalahmasalah yang dihadapinya. Apakah bisa bertahan? Charles Swindoll mengingatkan adanya "empat cacat rohani". (1) Pendapat bahwa karena kita orang Kristen, maka semua problema pasti teratasi; (2) Semua masalah yang akan Anda hadapi sebenarnya sudah dikatakan oleh Alkitab; (3) Jikalau mengalami masalah, berarti masih kurang rohani, dan (4) Penyingkapan pengajaran Alkitab yang dapat dipercaya secara otomatis mengatasi masalah-masalah.

\section{Prinsip Otoritas}

Ada dua macam otoritas, yaitu internal dan eksternal. Termasuk otoritas internal adalah kharisma, harga diri, kepribadian dan lain-lain yang menyebabkan seseorang mendapatkan penghargaan dari orang lain dan memberikan ciri khas terhadap para pemimpin alamiah. Otoritas eksternal sering didapat dengan manipulasi yang diberikan melalui kedudukan seseorang. Otoritas eksternal bersifat semu, sedangkan yang internal memiliki pengaruh yang lebih stabil.

\section{Prinsip Kesadaran Diri}

Prinsip ini paling sulit. Kebanyakan pemimpin tidak bisa menyadari dirinya itu seperti apa. Kesadaran diri itu bisa meningkatkan mutu kepemimpinan seseorang. Pemimpin-dan juga kebanyakan dari kitaacapkali lebih gampang melihat kelemahan dan kekurangan orang lain, daripada terhadap dirinya sendiri. Dia akan tahu kelemahan dan kekurangannya, jika dia juga mau terbuka terhadap kritik orang lain serta kesediaan untuk terus membina serta meningkatkan diri secara optimal. 


\section{PRINSIP-PRINSIP KEPEMIMPINAN}

\section{Berhubungan dengan Wibawanya}

Secara khusus Petrus Octavianus ${ }^{8}$ menyoroti perlunya wibawa yang harus dimiliki oleh seorang pemimpin. Menurutnya ada sepuluh langkah yang harus ditempuh oleh seorang pemimpin agar memiliki wibawa, yakni:

1. Kejujuran rohani. Seorang pemimpin harus bisa mengukur dan jujur dengan kerohaniannya sendiri. Jangan hanya menilai orang lain. Tidak boleh merasa sombong dan membanggakan diri dengan kelebihan dan karunia yang diberikan oleh Tuhan, sebaliknya harus disyukuri dan hanya dipakai untuk kemuliaan bagi nama Tuhan. Jangan sampai merampas dan mencuri kemuliaan Tuhan. Tanpa sikap demikian, maka ia akan gagal menjadi seorang pemimpin yang baik.

2. Rela menderita demi kasih Allah. Seorang hamba Tuhan yang mengalami penderitaan oleh karena iman dan pelayanannya, justru akan menjadikannya sebagai seorang pemimpin yang berwibawa. Bukan mencari-cari penderitaan, melainkan dengan sungguh-sungguh bergumul dengan air mata karena hidup dan pelayanannya sebagai hamba Tuhan atau orang Kristen, penderitaan oleh karena melayani tau menjadi pengikut Kristus, dan bukan karena kejahatan atau dosanya (1Ptr. 4:16). Seorang pemimpin yang sungguh-sungguh menjalankan kepemimpin-annya dengan banyak pergumulan, ia akan mendapat balasan dari Tuhan, berupa kesukacitaan. " Orang-orang yang menabur dengan mencucurkan air mata, akan menuai dengan bersorak-sorai. Orang yang berjalan maju dengan menangis sambil menabur benih, pasti pulang dengan sorak-sorai sambil membawa berkas-berkasnya. (Mzm. 126:5-6).

3. Kemauan untuk bekerja keras. Paulus memberikan teladan bagaimana dia tidak pernah main-main dalam pekerjaannya. Paulus menunjukkan kesungguhan dan keseriusannya dengan bekerja keras. Karena dia memiliki pengalaman dan contoh yang hidup, maka dia juga bisa menasihati Timotius untuk bekerja keras, karena, "Seorang petani yang

${ }^{8}$ Petrus Octavianus, Manajemen ..., 75-94. 
bekerja keras haruslah yang pertama menikmati hasil usahanya" (2Tim.2:16).

4. Berpandangan luas. Berpandangan luas merupakan salah satu seni seorang pemimpin. Hal ini bisa diperoleh melalui banyak belajar dan melihat dan mengalami. Oleh karena itu seorang pemimpin rohanin atau hamba Tuhan harus selalu meingkatkan diri dengan terus belajar. Tidak pernah ada istilah terlambat untuk belajar.

5. Bersifat objektif. Salah satu kesulitan yang banyak kita hadapi adalah berlaku dan bersikap objektif. Padahal dengan sikap objektif ini kita akan lebih gampang menarik orang lain untuk menerima diri kita serta pesan-pesan yang kita sampaikan. Sebaliknya, dengan bersikap subjektif, justru akan mengakibatkan orang lain menjadi menolak, bahkan antipati terhadap kita.

6. Pendirian rohani yang teguh. Ini sangat mutlak diperlukan oleh seorang pemimpin. Kalau pemimpin tidak mampu memberikan teladan rohani yang baik, niscaya ia akan gagal dalam menarik dan memimpin orang lain untuk mengikuti teladannya. Dengan memiliki pendirian rohani yang baik, maka akan terlihat kualitas kepemimpinan seorang pemimpin. Kepemimpinan yang berhasil adalah kepemimpinan yang bersifat spiritual centered leadership. Seorang pemimpin yang memiliki landasan rohani yang kokoh, tidak gampang kompromi dengan ketidakbenaran. Juga tidak gampang diombang-ambingkan dengan omongan orang lain yang tidak bertanggungjawab. Yang penting adalah bagaimana seorang pemimpin itu berdiri dengan jelas dalam pendirian rohani kita, sehingga setiap orang yang dipimpin tahu dan beridiri atas dasar itu.

7. Merendabkan diri. ${ }^{9}$ Kata ini gampang didengar, tetapi termasuk yang paling sulit untuk dilakukan. Merendahkan diri bukan rendah diri, tetapi humble, yang lebih dari sekedar rendah hati, dan merupakan suatu bukti akan karya Roh Kudus dalam hidup kita (1Kor. 9:22-23).

${ }^{9}$ Menurut Thomas Curtis, dalam merendahkan diri, seseorang harus rela dan bersedia untuk mendengarkan kritikan dan komplain dari orang lain. Practical Wisdom for Pastor, (Crossway Books, Wheaton, Illinois: 2001 ),123. 
Justru seorang pemimpin yang rela merendahkan diri maka dia pada akhirnya kan ditinggikan. Jika merendahkan diri itu untuk memenangkan jiwa dan memuliakan Allah, mengapa tidak melakukannya? Dalam 2 Korintus 11:7, rasul Paulus berkata, ”Apakah aku berbuat salah, jika aku merendahkan diri untuk meninggikan kamu, karena aku memberitakan Injil Allah kepada kamu dengan cumacuma?" Tentu tidak ada alasan bagi Paulus untuk tidak merendahkan diri, karena Tuhan Yesus sendiri memberikan keteladanan yang sempurna. "Dan dalam keadaan sebagai manusia, Ia telah merendahkan diri-Nya dan taat sampai mati, bahkan sampai mati di kayu salib.” (Flp. 2:8).

8. Mengorbankan harta milik. Anda mungkin pernah mendengar ada anggota jemaat atau rekan yang berujar, "Hamba Tuhan itu lebih kaya dari pengusaha di gerejanya". Kalimat ini seringkali memang ada benarnya. Ada hamba Tuhan yang memiliki banyak sekali kekayaan yang didapat dari persembahan jemaat. Hamba Tuhan banyak menghimbau jemaat untuk memberi, tetapi dia sendiri kurang rela memberi. Beberapa kali saya menyaksikan ada hamba Tuhan yang ketika kantong kolekte disodorkan kepadanya oleh petugas hanya direspons dengan anggukan kepala atau lambaian tangan sebagai isyarat supaya kantong itu tidak usah mampir kepadanya. Di mana letak keteladanan untuk memberi? Benarkah hamba Tuhan hanya berhak menerima dan tidak berkewajiban untuk memberi? Apakah hanya jemaat yang wajib memberi? Justru seorang hamba Tuhan atau pemimpin rohanilah yang pertama-tama harus memberikan teladan dalam memberi, bukan jemaat atau orang yang dipimpinnya. Berikut ini beberapa contoh yang bisa diteladani:

- Persembahan yang berkelimpahan untuk kepentingan pendirian rumah Tuhan (Kel. 36:1-7).

- Persembahan seorang janda Sarfat. Ia memberikan semua yang dimiliki kepada nabi Elia (1Raj. 17:7-16)

- Persembahan janda miskin di Bait Allah (Mat. 12:42-44)

- Persembahan jemaat mula-mula (Kis. 4:32-37)

- Persembahan jemaat Makedonia (2Kor. 8:1-7) 
- Persembahan seorang wanita di Betania (Mat. 26:6-13).

- Murid-murid Yesus yang harus meninggalkan segala sesuatu untuk mengikut Tuhan (Mat. 4:18 dyb.; 19:16 dyb).

9. Menjaga kesucian. Hidup suci atau kudus_apalagi bagi seorang pemimpin atau hamba Tuhan-bukan sekedar suatu usaha, tapi keharusan. Ini adalah perintah Tuhan. Dengan mengutip dari kitab Imamat 11:44-45, rasul Petrus menyampaikan pesannya kepada jemaat-jemaat yang tersebar di Asia Kecil, demikian: "tetapi hendaklah kamu menjadi kudus di dalam seluruh hidupmu sama seperti Dia yang kudus, yang telah memanggil kamu, sebab ada tertulis: Kuduslah kamu, sebab Aku kudus." (1Ptr. 1:15-16). Jadi kekudusan itu merupakan harga mati yang tidak bisa ditawar-tawar. Suatu keharusan bagi para pemimpin rohani, hamba Tuhan dan bahkan bagi setiap orang Kristen. Alasannya jelas. Karena tubuh kita adalah bait Allah (1Kor. 3:6-17) sehingga kita harus tetap menjaga kekudusannya.

10. Memiliki penglihatan (visi) yang hidup. Penglihatan yang hidup bukan, bukan mimpi, bukan khayalan, melainkan visi. Seorang pemimpin rohani dan hamba Tuhan harus memiliki mata Allah untuk melihat. Telinga Tuhan untuk bisa mendengar. Hati Allah untuk bisa simpati dan empati. Pikiran Allah untuk memikirkan hal-hal yang baik dan benar. Dengan demikian maka ia akan bisa berjalan dalam kebenaran. Akan bisa melakukan segala sesuatu sesuai dengan kehendak dan rencana Allah. Apa yang kita lakukan adalah apa yang Allah inginkan untuk kita lakukan. Bukan berasal dari ambisi dan "visi diri". Penglihatan yang hidup adalah penglihatan yang datang dari Tuhan sendiri yang memberikan kepada kita keberanian untuk bertindak. Seorang pemimpin harus memiliki visi yang jelas dalam hidupnya, bukan sekedar melakukan apa adanya. Obsesi harus disertai dengan visi yang dipimpin oleh Roh Kudus.

\section{B. Berhubungan dengan sikap-sikapnya.}

1. Harus memandang positif setiap kesulitan yang ada. Kesulitan dapat membawa kita kepada ketidakmampuan dan frustrasi. Tetapi disisi lain 
kesulitan dan kegagalan juga dapat menimbulkan daya kreativitas yang membangun.

2. Menghindari ketegangan. Humor kadang-kadang diperlukan oleh seorang pemimpin. Humor juga merupakan karunia dari Tuhan. Humor bukan sekedar melucu, dan harus dapat dikendalikan. Karena itu jangan membuat humor yang menyimpang.

3. Bisa mengontrol amarah. Setiap orang bisa marah. Tetapi marah menjadi dosa apabila berpusat pada diri. Kemarahan yang suci adalah kemarahan yang berpusat pada kemuliaan Tuhan. Tuhan Yesus juga marah terhadap orang-orang yang degil hatinya (Yoh. 2:15-17). Ia juga marah kepada para murid karena kurang beriman (Mat. 8:23-27; 4:35-41; Luk. 8:22-25. Marah yang "benar" sebagaimana ditulis oleh Rasual Paulus dalam Ef. 4:26.

4. Memelihara kesabaran. Salah satu buah Rohkudus yang sangat menentukan dalam hidup adalah kesabaran. Tuhan menuntut kesabaran (2Ptr. 1:15-17).

5. Mengasibi setiap orang yang dipimpinnya. Kasih itu melebihi iman dan pengharapan. Kasih juga menjadi pengikat persahabatan (Yer. 31:3; 1 Kor. 13:13).

6. Mengusahakan dan memelihara persahabatan. 2Sam. 23:15-16 adalah contoh yang sangat baik. Daud tahu bagaimana menempatkan diri baik sebagai teman/sahabat maupun pemimpin.

7. Meneladani Kristus. Mengapa harus meneladani-Nya? Karena Dia adalah satu-satunya pemimpin yang paling sempurna dan ideal. Paulus mengatakan, "Jadilah pengikutku, sama seperti aku juga menjadi pengikut Kristus" . Kalimat ini juga bisa diterjemahkan, "Teladanilah aku, sama seperti aku juga meneladani Kristus” (1Kor. 11:1). 


\section{Berhubungan dengan tugas utamanya: Membuat keputusan. ${ }^{10}$}

1. Mengambil keputusan dengan bijaksana. Agar seorang hamba Tuhan dapat mengambil keputusan dengan bijaksana, maka ia harus memiliki sikap dan disiplin bergantung kepada Tuhan (Mzm. 127:1). ${ }^{11}$ Seorang pemimpin harus menentukan arah kebijaksanaannya dengan jelas, yang memungkinkan setiap anggota dalam lembaga yang dipimpinnya bersama menerima arah kebijaksanaan itu. Setiap pribadi harus bekerjasama dalam rel yang tepat dalam garis yang jelas.

2. Menentukan metode/sistem yang dipakai. Dengan menentukan metode yang tepat, maka segi-segi yang positif dapat berkembang dengan baik, sedangkan segi-segi yang negatif akan dapat dikurangi. Jadi metode merupakan sarana untuk mencapai sasaran-sasaran yang dapat menampung kebijaksanaan dan arah pekerjaan.

3. Menentukan prosedur yang berlaku. Metode yang baik harus disertai dengan prosedur yang tepat. Setiap bagian harus merasakan nilai arti keterpaduan.

4. Mengawasi dan menegakkan disiplin. Seorang pemimpin bukan hanya duduk di belakang meja, namun dia juga harus melaksanakan fungsi pengawasan-bukan mencari-cari kesalahan-dan menegakkan disiplin yang dipimpinnya. Untuk ini tentu saja dia harus terlebih dahulu bersikap dan bertindak disiplin. Tegas, bukan keras.

5. Mengontrol secara keseluruban. Meskipun seorang pemimpin barangkali memiliki sejumlah 'asisten' atau wakil, namun dia juga harus mampu melaksanakan fungsi controlling dengan baik. Hal ini bukan berarti dia tidak boleh memercayai orang yang telah dipercayainya.

10 Petrus Octvianus, Manajemen ..., 95-98

11 Jerry Bridges, The Discipline ..., 143. 


\section{Berhubungan dalam Membuat Keputusan}

Seorang pemimpin apabila membuat keputusan harus benar-benar bijaksana. Oleh karena itu dalam mengambil keputusan, seorang pemimpin harus: ${ }^{12}$

1) Meyakini kehendak Tuban. Seorang pemimpin harus yakin bahwa keputusan yang diambilnya merupakan kehendak Tuhan. Untuk itu keputusan tidak boleh sembrono, tapi sebelum memutuskan harus terlebih dahulu meminta petunjuk dan pimpinan Tuhan.

2) Keputusan yang jelas dan tegas, sehingga:

(a) Dapat menolong orang lain mengikuti dan melaksanakan keputusan tersebut tanpa ragu-ragu.

(b) Dengan keputusan yang jelas, akan membuat orang lain juga rela untuk berkorban.

3) Keputusan terarah pada tujuan tunggal yang luas. Seorang pemimpin jangan membuat keputusan-keputusan dengan tujuan yang "terlalu" kecil. Dalam gereja, harus berorientasi pada tujuan menjadikan jemaat yang misioner, demi pertumbuhan dan perkembangan jemaat secara keseluruhan.

4) Keputusan sesuai dengan prioritas. Berarti harus tahu mana yang harus didahulukan. Hal ini memiliki beberapa keuntungan, antara lain:

- Tahu bahwa semua tidak bisa dikerjakan sama baiknya dalam waktu yang bersamaan.

- Hasil yang maksimal dan baik itu pertama-tama harus memuaskan Tuhan, baru untuk kepuasan orang lain dan diri sendiri.

Untuk hal ini ada beberapa hal yang harus dipertimbangkan, yaitu:

- Hal-hal yang jarang terjadi atau yang mungkin tidak terduga

12 Petrus Octavianus. Manajemen dan Kepemimpinan Menurut Wabyu Allah. Batu: Departemen Literatur YPPII, 2007, 99-122) 
- Luasnya jangkauan pelayanan dan pentingnya mereka yang hendak dicapai

- Memelihara apa yang sudah Tuhan berikan

- Prioritas itu senantiasa bersangkutpaut dengan pengertian terhadap seluruh pelayanan dengan akibat yang luas, bagi kemuliaan Tuhan, dst.

5) Harus rela membayar biaya dari keputusan yang diambilnya.

- Harus siap untuk dikritik dan menanggung risiko/akibat dari keputusannya.

- Untuk mengambil keputusan secara efektif melayani Tuhan, juga harus rela untuk meninggalkan keluarga maupun orang tua.

- Memiliki kesediaan untuk membersihkan diri dari si Aku.

6) Berani bertanggungjawab terhadap setiap kegagalan. Jika ada anggota yang bersalah, seorang pemimpin harus berani mengambil tanggung jawab. Dengan demikian maka:

- Bawahan akan merasa tertolong, karena bukan bawahan yang justru dikorbankan.

- Terbukti bahwa pemimpin adalah seorang pelindung.

7) Berani melaksanakan keputusan yang diambilnya. Bagaimana pun, seorang pemimpin harus berani mengambil risiko untuk tetap melakukan dengan konsisten keputusan yang telah diambilnya, kecuali itu nyatanyata akan merugikan banyak pihak dan bukan semata-mata hanya karena akan merugikan dirinya.

\section{KARAKTERISTIK GAYA KEPEMIMPINAN PELAYAN}

Berikut ini adalah daftar karakteristik yang memerlihat-kan pertentangan antara kepemimpinan yang mengandalkan pada kekuasaan dengan kepemimpinan pelayan, sebagaimana ditulis oleh Stacy Rinehart ${ }^{13}$

${ }^{13}$ Stacy T. Rinehart. Upsidedown: The Paradox of Servant Ledership (Penerbit Immanuel, Jakarta: 2003), 167-168. 


\begin{tabular}{|c|c|}
\hline $\begin{array}{l}\text { Kepemimpinan yang } \\
\text { mengandalkan kekuasaan }\end{array}$ & Kepemimpinan pelayan (167-8) \\
\hline $\begin{array}{l}\text { - Titik pusat adalah pelayan } \\
\text { - Tidak mengembangkan } \\
\text { pemimpin lain } \\
\text { - Terjadi banyak pergantian } \\
\text { ketika orang meninggalkan } \\
\text { pelayanan } \\
\text { - Memertahankan fokus pada diri } \\
\text { dan agenda mereka } \\
\text { - Tidak dapat membangikan } \\
\text { agenda } \\
\text { - Hidup dari posisi yang } \\
\text { berwenang dan memiliki } \\
\text { kekuasaan } \\
\text { - Meninggalkan orang dalam luka } \\
\text { batin dan tersiksa } \\
\text { - Sering menunjuk pada gelar } \\
\text { mereka } \\
\text { - Pakar dalam memanipulasi } \\
\text { dan/atau menyalahgunakan } \\
\text { mereka yang berada pada jalan } \\
\text { mereka } \\
\text { - Memakai gambaran kekuasaan, } \\
\text { jasa dan suka mengungkapkan } \\
\text { posisi mereka } \\
\text { untuk memeroleh jalan mereka } \\
\text { pekerjaan mereka. }\end{array}$ & $\begin{array}{l}\text { - Membagi sorotan itu dengan } \\
\text { orang lain } \\
\text { - Titik pusat pada Yesus } \\
\text { - Mengembangkan banyak orang } \\
\text { - Sedikit terjadi pergantian yang } \\
\text { rendah karena orang tetap } \\
\text { tinggal dan setia } \\
\text { - Menjadikan Kristus sebagai } \\
\text { fokus dan agenda } \\
\text { - Memerkokoh dan terlibat } \\
\text { dalam agenda Kerajaan Allah } \\
\text { - Berikrar pertama-tama dan } \\
\text { terutama untuk menjadi } \\
\text { pelayan } \\
\text { - Berikrar untuk merekonsiliasi } \\
\text { dan membangun hubungan } \\
\text { - Mungkin memiliki gelar tetapi } \\
\text { jarang menunjuk pada gelar itu } \\
\text { - Menghargai orang untuk } \\
\text { kebebasan mereka dalam } \\
\text { berpikir, bertindak dan } \\
\text { menanggapi } \\
\text { - } \text { Benci akan pikiran yang } \\
\text { memakai gambaran kekuasaan } \\
\text { orang atau mendekati mereka } \\
\text { karena kedudukan mereka } \\
\text { pengikut bagi Tuhan } \\
\text { - }\end{array}$ \\
\hline
\end{tabular}




\section{BELAJAR DARI KEPEMIMPINAN PAULUS}

Tidak bisa dipungkiri bahwa rasul Paulus adalah salah satu pemimpin yang paling hebat dalam bangkit dan berkembangnya kekristenan mulamula. Tanpa Paulus pasti sejarah kekristenan tidak akan seperti yang sekarang kita lihat. Memang harus diakui, bahwa selain Paulus, Tuhan juga menyiapkan rasul-rasul lain yang ditugasi untuk mengamankan dan melaksanakan Amat Agung Tuhan Yesus. Meski tidak secara langsung Paulus berbarengan dengan para murid Tuhan Yesus, namun pertemuan dan pertobatannya yang spektakuler itu (Kis. 8 dan 9), telah membawanya untuk menjadi seorang hamba Tuhan yang sangat militan. Justru dari sisi gelap kehidupan Paulus sebelum bertobat itulah yang banyak memengaruhi pola pikir, sikap, ucapan dan tindakannya, yang kadang-kadang mengejutkan. Berikut penulis rangkumkan kekuatan dan kelemahan kepemimpinan Paulus yang diharapkan bisa menjadi inspirasi bagi kita.

\section{A. Kekuatan Kepemimpinan Paulus}

1. Tuhan adalah sumber kepemimpinannya: dipanggil dan dipercayai oleh Tuhan (Kis. 26:16-18; Rm. 15:15-16; 1Kor. 4:1-2). Ini menjadi dasar otoritas dirinya, dan diakui kerasulannya (Gal. 2:1-10)

2. Sumber daya manusia yang amat baik: pendidikannya, kefarisiannya, dst. (Flp. 3:5-6). Yang jauh lebih penting dari semua itu adalah panggilan Tuhan terhadap dirinya untuk menjadi seorang pemimpin (Kis. 9, 22, 26)

3. Doa menjadi sumber kekuatan dalam kepepimpinannya: doa pribadi (Ef. 3:14-21); doa orang-orang kudus (Ef. 6:19) dan mendoakan timnya (Flp. 1:4-5).

4. Pola kepemimpinanya. Pemuridan (2Tim. 2:2); pendelegasian (Tit. 1:5); penjelajahan (Rm. 15:18-24). Seorang body building/ pembangun tubuh, dengan meletakkan tatanan yang kokoh (50\% dari Perjanjian Baru [13 surat] ditulis oleh Paulus).

5. Sasaran kepemimpinannya: terutama ditujukan kepada orang-orang kafir (Rm. 15:15-16), juga kepada sesama Yahudi (Kis. 13:46).

6. Kepemimpinan yang mengutamakan dasar kesatuan dan keutuhan tubuh Kristus: kiasan tubuh, perjamuan kudus, dimana semua unsur menjadi kesatuan dan kemanunggalan (1Kor. 12, 
7. 14). Itu sebabnya, maka ia membela gereja Tuhan dari serangan guruguru palsu (Kis. 20:17-38).

8. Ketegasan kepemimpinannya: disiplin terhadap diri sendiri (1Kor. 9:27); disiplin gereja melalui Timotius (1Tim. 5:19-25). Ia adalah seorang pemimpin yang berpegang pada prinsip (Gal. 2:11-14).

9. Seorang pemimpin yang tipikal: pekerja keras (1Tes. 5:12-15); keterbukaan, suka sharing (Flp. 1:1). Tidak membangun pekerjaan di atas dasar karya orang lain (Rm. 15:20). Ia adalah seorang yang berkarya hingga pada akhirnya (2Tim. 4:7). Ia juga orang yang mampu bersikap positif terhadap apa-apa yang negatif (2Kor. 12:7).

10. Kerendahhatiannya: rela hidup damai dengan jemaat (1Tes. 5:13); sikap meneladani Kristus (Flp. 2:3-8); menjadikan dirinya teladan jemaat, seperti dia juga meneladani Kristus (1Kor. 11:1); mengakui bahwa dirinya juga manusia yang lemah (2Kor. 12:10); rela melepaskan hak (1Kor. 9:4-10); bahkan rela memberi dan berkorban (2Kor. 9:6-9).

11. Selalu menempatkan diri secara bijak (1Kor. 9: 20): di antara orang Yahudi berperan sebagai orang Yahudi, tetapi jika diantara orangorang bukan Yahudi, ia juga berperan sebagai orang bukan Yahudi. Demikian pula, ketika ia berada (a) di Atena ia menampakkan dirinya sebagai seorang filsuf; (b) di Galatia ia berlaku keibuan; (c) di Efesus ia bersifat kebapaan.

\section{B. Kelemahan Kepemimpinan Paulus}

1. Tidak sabaran dalam menangani rekan kerja, misalnya: soal Markus (Kis. 15:38-39).

2. Ketidakseimbangan antara semangat penginjilan dan penggembalaan.

3. Kelebihan sekaligus kelemahannya: gila kerja (workalholic).

4. Kelemahan fisik yang disebutnya sebagai duri (2Kor. 12:7)

\section{Peluang Kepemimpinannya}

Ia adalah seorang yang selalu melihat peluang: saat penjara digoncang gempa, ia tetap bertahan Dan itu menjadi peluang baginya untuk memenangkan jiwa (Kis. 16); perdebatan di Atena (Kis. 17); di hadapan Feliks ia menginjili (Kis. 24); minta kepada Festus untuk diadili di Roma dengan tujuan penginjilan (Kis. 25); juga kepada Agripa ia bersaksi (Kis. 26); saat kapal kandas, ia pun masih memanfaatkan peluang untuk bersaksi 
(Kis. 27); saat melihat motivasi pelayanan yang tidak sehat ia tetap melihatnya sebagai peluang untuk pemberitaan Kristus (Flp. 1:12-18).

\section{Ancaman terhadap Kepemimpinannya}

1. Gaya pendekatan Paulus yang hampir selalu frontal sehingga bisa menimbulkan reaksi perlawanan (2 Kor. 11:23-29).

2. Keberhasilannya dalam menangani pihak-pihak bukan Yahudi selalu memancing kecemburuan orang-orang Yahudi lainnya, sehingga mereka selalu membayangi perjalanannya, untuk merusak, memfitnah, dan mengacaukan orang-orang yang baru ia layani (Kis. 18:9 dyb).

\section{PENGHAMBAT PERKEMBANGAN PELAYAN ${ }^{\mathbf{1 4}}$}

Para peneliti Amerika di bidang sosial dan psikologi melaporkan bahwa kebanyakan orang gagal dalam pekerjaan dan pelayanannya dikarenakan oleh beberapa faktor. Berikut ini rangkuman penelitian itu.

1. Kegagalan memimpin administrasi (menurut Ketua Hubungan Masyarakat di Chicago)

- Pandangan yang kurang luas dan berhati sempit. Untuk mencari keuntungan sendiri yang hanya sedikit, ia rela untuk mengorbankan atau menyingkirkan orang-orang yang berbakat dan berkemampuan baik.

- Kurangnya rasa tanggung jawab pribadi dan terhadap tugas.

- Kurang gairah dan semangat kerja serta tidak setia dalam menjalankan tugas. Gampang berpaling untuk mencari pekerjaan baru.

- Kurang tekun dan sabar, mudah melarikan diri dan bersifat kompromis dalam menghadapi masalah.

- Kurang memiliki kemampuan untuk bersatu, sulit bekerjasama dengan orang lain (mungkin hal ini disebabkan karena merasa diri lebih pandai atau sebaliknya, serta tidak mau mendengar kritikan dari orang lain).

${ }^{14}$ Diadaptasi dari buku karangan Dr. Peter Wongso, Theologia Penggembalaan, (Malang: Seminari Alkitab Asia Tenggara, 1991), 17-22. 
- Kurang memiliki kemauan untuk taat, sebaliknya lebih suka melanggar dan melawan arus.

- Kurang memerhatikan kebutuhan bawahan dan bersikap congkak atau arogan.

- Tidak memiliki kemampuan untuk membedakan antara yang benar dan yang salah, antara yang prinsip dan yang bukan prinsip.

- Tidak memiliki kemampuan untuk menahan (mengontrol) diri.

- Kesehatan jiwa terganggu, emosinya tidak stabil.

2. Jurusan Perdagangan Universitas Emony di AS yang menyelidiki kemudian menyimpulkan alasan pemecatan perusahaan terhadap para karyawannya.

- Karena tidak luwes, atau tidak pandai berkata-kata.

- Kurang sopan santun.

- Jiwanya belum matang, sehingga tidak bisa menghadapi masalah secara dewasa.

- Kehidupan keluarga dan rumah tangga yang kacau/tidak beres.

- Tidak memiliki rasa humor (sense of humor).

- Selalu bersikap curiga.

- Malas bekerja.

- Tidak menghargai pengalaman orang lain, suka memertahankan pendapat sendiri.

- Suka berkhayal yang tidak rasional, pikirannya tidak praktis.

- Suka ngrasani (gosip) terhadap rekan kerja atau bosnya yang terdahulu.

3. Krisis atau penyebab kegagalan pendeta

- Dari segi profesionalisme. Karena terlalu banyak khotbah, melayani, sehingga pada akhirnya dirinya menjadi "kering". Karena itu seorang hamba Tuhan harus selalu membuat penyegaran diri.

- Congkak. Merasa lebih rohani, lebih hebat dalam berkhotbah, lebih berhasil dalam pelayanan, dsb. sehingga merendahkan hamba Tuhan/orang lain. 
- Dengki dan iri hati. Merasa tidak puas, tidak senang dan tidak dapat bersuka cita dengan orang yang bersukacita. Tidak ikut bersyukur atas keberhasilan rekan kerja atau hamba Tuhan lainnya.

- Harga diri. Anda mungkin sudah pernah mendengar sebuah dongeng kuno dari Indonesia yang menceritakan tentang seekor kura-kura yang dapat terbang. Sebenarnya tidak benar-benar bisa terbang, tapi karena dia menggigit sebatang kayu yang dibawa oleh dua ekor angsa yang terbang membawanya. Pada saat orang-orang dari darat yang melihatnya berkata, "Wah, cemerlang sekali ide angsa-angsa itu, bisa membawa terbang kura-kura seberat itu!" Mendengar hal itu harga diri kura-kura tadi sangat terluka, sehingga dia berteriak, "Aaahh. Itu 'kan ideku!" Tentu saja bersamaan dengan itu ia akhirnya kehilangan pegangan dan melayang jatuh ke tanah yang berbatu. Harga dirinya telah menjadi sumber kehancuran bagi dirinya sendiri. Amsal memberikan petuahnya, "Kecongkakan mendahului kehancuran dan tinggi hati mendahului kejatuhan." (Ams. 16:18).

- Terlalu mengasihani diri sendiri atau terlalu sayang diri. Ini menjadi sumber kemalasan bagi setiap orang. Alasan capek, mengantuk, tidak enak badan, sibuk, dsb. yang sebenarnya adalah sifat malas dan menasihani diri sendiri.

- Sikap tidak man mengampuni. Charles Swindol15 mengatakan bahwa mengampuni itu bisa diibaratkan sebagai suatu mata pelajaran, tapi bukan suatu mata pelajaran pilihan, melainkan pelajaran wajib, yang tidak gampang untuk memeroleh kelulusan dalam ujian. Maksud Swindoll jelas. Mengampuni itu bukan persoalan yang gampang, tapi setiap orang harus belajar untuk mengampuni. Tuhan Yesus sendiri telah mendemonstrasikan bagaimana kita harus mengampuni orang lain; ketika Dia berhadapan dengan perumpamaan yang didapati berzina oleh orang-orang Farisi (Yohanes 8). Pada bagian lain dipaparkan bagaimana Petrus yang sudah mengampuni saudaranya sebanyak tujuh kali, tapi Tuhan Yesus masih menganggapnya kurang, sehingga dikatakan harus mengampuni sampai 70 kali 7 kali, artinya unlimited, tak terbatas (Mat. 18:21-35). Mengampuni berarti

${ }^{15}$ Charles Wsindol, Improving ..., 61 dyb. 
melupakan dan tidak mendendam. Pengampunan secara horizontal, terhadap sesama harus kita, harus dilakukan secara tuntas, karena kita sudah menerima dan mengalami pengampunan dari Tuhan Yesus (pengampunan vertikal), sehingga kita juga harus mengampuni sesama kita (pengampunan horizontal). Kalau kita berbuat salah kepada sesama, kita harus minta maaf, minta pengampunan baik secara vertikal maupun secara horizontal. Mengampuni (dan juga minta ampun/maaf) harus dilakukan baik terhadap Tuhan maupun sesama di mana kita berbuat salah. Pengakuan kepada Tuhan "tidak cukup", sampai kita secara jujujr dan terbuka juga harus mengakui/menyatakannya di depan orang yang berbuat salah atau yang kepadfanya kita bersalah. Mengampuni (memaafkan) atau minta ampun (maaf) harus dilakukan baik kepada Tuhan maupun manusia yang bersalah kepada kita, atau kita bersalah kepadanya. Jika demikian, maka barulah masalah itu beres. Mengampuni juga berarti melupakan kesalahan orang lain terhadap kita. "Melupakan"16 berarti: (1) menolak untuk menyimpan dendam (1Kor. 13:5); (2) mampu menahan diri dari melakukan pelanggaran (Mzm.119:165) dan (3) tidak memiliki sikap menghakimi (Mat. 7:1-5). Dengan demikian barulah kesalahan atau dosa yang kita buat itu dibereskan.

- Masalah uang. Di depan sudah disinggung sedikit tentang hal ini. Tetapi di bagian ini akan kembali diperjelas.

(a) Penyebab krisis. Uang seringkali menjadi sumber dan penyebab krisis. Oleh karena hamba Tuhan ingin kenikmatan jasmani, ia lalu diperbudak oleh uang. Mungkin tuntutan keluarga memang terlalu banyak. Ditambah lagi kalau tidak bisa mengelola keuangan dengan baik. Memang kekurangan atau ketidakcukupan hamba Tuhan dalam hal materi sering menjadi cobaan yang besar.

(b)Bagaimana mengatasinya? Hamba Tuhan sebaiknya jangan mengurusi keuangan gereja. Jika terpaksa harus mengatur keuangan umum, harus dipisahkan dengan keuangan pribadi. "Belajar mencukupkan diri, dan jangan memikirkan hal-hal yang

${ }^{16}$ Richard Swindoll, Improving ..., 83. 
terlalu tinggi. Janganlah kamu memikirkan hal-hal yang lebih tinggi dari pada yang patut kamu pikirkan, tetapi hendaklah kamu berpikir begitu rupa, sehingga kamu menguasai diri menurut ukuran iman, yang dikaruniakan Allah kepada kamu masingmasing." (Rm.12:3). Lebih baik diri sendiri rugi daripada merugikan orang lain. Bertanggung-jawablah kepada Tuhan, dan mintalah kepada-Nya apabila kita kekurangan "... Allahku akan memenuhi segala keperluanmu menurut kekayaan dan kemuliaan-Nya dalam Kristus Yesus.” (Flp. 4:19).

- Masalah seks atau hubungan dengan lawan jenis. Masalah seks atau hubungan antara laki-laki dan perempuan sering menjadi jebakan bagi hamba Tuhan. Sering terjadi bahwa dalam kasus pastoral terhadap lawan jenis telah menjadi jerat baginya. Karena itu seorang hamba Tuhan harus selalu bersikap hati-hati dan memegang prinsip pelayanan (termasuk konseling pastoral) dengan baik. Jangan merasa diri terlalu kuat untuk tidak jatuh dalam dosa seksual (mengapa?).

- Kedudukan: Jangan menjadikan kedudukan sebagai tujuan utama pelayanan kita. Hal ini bisa menyebabkan terjadi saling sikut dan menjatuhkan antar sesama hamba Tuhan (hal ini bisa terjadi jika di dalam gereja atau pelayanan ada beberapa hamba Tuhan, ada gembala senior dsb.). Itulah sebabnya maka Richard Foster secara khusus menulis dalam bukunya Sex, Money, and Power tentang bahaya 3-TA (harta/uang, tahta/kedudukan dan seksualita) sebagai bahaya paling serius yang sering dihadapi oleh para hamba Tuhan.

\section{KESIMPULAN}

Kepemimpinan itu bukan sekedar skill atau talenta, tetapi lebih daripada itu, kepemimpinan adalah sebuah seni. Kita bisa menguasai teori kepemimpinan apa pun, tetapi kita bisa gagal. Kadangkala orang yang secara teoretis pemahamannya soal organisasi dan kepemimpinan begitu sluas, namun dalam praktiknya tidak berbanding lurus dengan pengetahuan dan teori yang dimilikinya. Tetapi sebaliknya ada orang yang pengetahuannya tentang kepemimpinan begitu cethek, tapi justru bisa 
menjadi seorang pemimpin yang berhasil. Karena kepemimpinan yang sejati adalah pemimpin yang tidak selalu berjalan di depan. Adakalanya perlu di samping sebagai penopang, atau bahkan di belakang agar dapat memberikan dorongan kepada yang dipimpinnya. Pempimpin yang baik adalah pemimpin yang bisa memberi, dan bukan selalu menuntut. Memberikan beban, tugas dan tanggung jawab kepada yang dipimpinnya, tetapi tidak untuk membebaninya, seperti yang dikatakan-Nya, "Sebab kuk yang Kupasang itu enak, dan beban-Ku pun ringan’. (Matius 11:30)

Hadi P. Sahardjo, menyelesaikan pendidikan teologinya di Seminari Alkitab Asia Tenggara, Malang (B.Th., S.Th., M.A. dan M.Div.) dan International Theological Seminary, ITS, Los Angeles, USA (Th.M.), serta D.Th. (Asian Baptist Graduation Theological Seminary/STBI Semarang). Gelar Drs. (Doktorandus) di bidang Psikologi Pendidikan dan Bimbingan Konseling dari IKIP (sekarang Universitas) Negeri Malang. Saat ini penulis menjadi dosen tetap dan Pembantu Ketua III/Bid. Kemahasiswaan/Pelayanan di ST'T SAPPI. 